\title{
Sex differentiation in Atlantic cod (Gadus morhua L.): morphological and gene expression studies
}

\author{
Trine Haugen ${ }^{*}$, Fernanda FL Almeida ${ }^{2,4}$, Eva Andersson ${ }^{1}$, Jan Bogerd ${ }^{2}$, Rune Male $^{3}$, Katrine S Skaar ${ }^{3}$,
} Rüdiger W Schulz ${ }^{2}$, Elin Sørhus ${ }^{1}$, Tim Wijgerde ${ }^{2}$ and Geir L Taranger ${ }^{1}$

\begin{abstract}
Background: In differentiated gonochoristic species, a bipotential gonad develops into an ovary or testis during sex differentiation. Knowledge about this process is necessary to improve methods for masculinizing genetically female Atlantic cod for the subsequent purpose of producing all-female populations.

Methods: Gonads were examined histologically in juveniles from 14 to $39 \mathrm{~mm}$ total body length (TL). Number and size of germ cells were determined in a subset of the samples. Relevant genes were cloned, and mRNA levels determined by qPCR of amh, cyp19a1a; dax1 (nrob2); shp (nrob2a) and sox9b in a mixed-sex and an all-female population ranging from $12-49 \mathrm{~mm} \mathrm{TL}$.

Results: Individuals between 14-20 mm TL could be separated in two subgroups based on gonad size and germ cell number. Ovarian cavity formation was observed in some individuals from $18-20 \mathrm{~mm}$ TL. The mixed sex population displayed bimodal expression patterns as regards cyp19a1a (starting at $12 \mathrm{~mm} \mathrm{TL}$ ) and amh (starting at $20 \mathrm{~mm}$ TL) mRNA levels. After approximately $30 \mathrm{~mm}$ TL, cyp19a1a and amh displayed a gradual increase in both sexes. No apparent, sex-dependent expression patterns were found for dax1, shp or sox $9 b$ transcripts. However, shp levels were high until the larvae reached around $35 \mathrm{~mm} \mathrm{TL}$ and then dropped to low levels, while dax 1 remained low until $35 \mathrm{~mm} \mathrm{TL}$, and then increased sharply.

Conclusions: The morphological sex differentiation in females commenced between 14-20 mm $\mathrm{TL}$, and ovarian cavities were evident by $18-20 \mathrm{~mm}$ TL. Testis development occurred later, and was morphologically evident after $30 \mathrm{~mm}$ TL. This pattern was corroborated with sexually dimorphic expression patterns of cyp19a1a from 12-13 mm $T L$, and a male-specific increase in amh from $20 \mathrm{~mm} T L$.
\end{abstract}

Keywords: Atlantic cod, Sex differentiation, Aromatase, cyp19a1a, Anti-müllerian hormone, amh, dax1, shp, Masculinization

\section{Background}

All female populations of Atlantic cod (Gadus morhua) are desired in aquaculture to prevent possible genetic impacts on wilds stocks from fertilized eggs spawned in cages. All female populations is even more beneficial if combined with triploidy, as triploid fish normally do not develop large gonads and secondary sex characters that are regarded negative in the grow-out phase in aquaculture $[1,2]$. All female populations are most commonly produced by using sperm from masculinized XX females [3,4].

\footnotetext{
* Correspondence: trine.haugen@imr.no

'Institute of Marine Research, Nordnes, P.O. Box 1870, N-5817, Bergen, Norway Full list of author information is available at the end of the article
}

However, in order to successfully masculinize fish, the timing of sex differentiation (time window when the fish are labile to phenotypical sex change), must be known.

Sex differentiation is the complex process of developing a functional testis or an ovary from a bipotential vertebrate gonad [5]. In fish, maternally transferred mRNAs, necessary for the formation and migration of primordial germ cells (PGCs), is segregated asymmetrically into the future PGCs [6]. The PGCs migrate towards the gonadal ridge [7], where they become enclosed by somatic gonadal cells [8]. The PGCs remain quiescent in the undifferentiated gonad for a period of time [9], before they start to proliferate and differentiate into

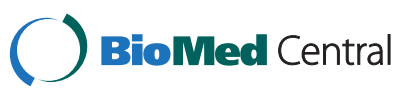


oogonia or spermatogonia upon extrinsic cues. The timing of sex differentiation varies between teleost species, and it can occur very early as in medaka (Oryzias latipes) with increasing numbers of germ cells in presumptive females already at hatching [10], intermediate as in zebrafish (Danio rerio) (21-25 day post hatching) [11], or late in juvenile stages as in sea bass (Dicentrarchus labrax) (120-150 days post fertilization) [12,13] and Atlantic halibut (Hippoglossus hippoglossus) at approximately $38 \mathrm{~mm}$ fork length [14].

Some common features are observed during sex differentiation in different fish species. One is the upregulation of expression of the cyp19a1a gene. Cyp19a1a protein catalyzes the conversion of androgen into estrogen, which drives ovarian differentiation [15-17]. Sex specific expression of cyp19a1a in the gonads has been observed for example in southern flounder (Paralichthys lethostigmata) [18] and Nile tilapia (Oreochromis niloticus) before and during sex differentiation $[19,20]$.

Anti-Müllerian hormone (Amh) is well studied in mammals, but less so in teleosts. In mammals, Amh induces regression of the Müllerian duct during male sex differentiation, and also modulates the differentiation of Leydig cells by down-regulating the expression of several genes coding for steroidogenic enzymes [21], and it inhibits expression of the aromatase gene during sex differentiation [22]. Teleosts have no Müllerian duct, but Amh has been shown to inhibit steroidogenesis in adult zebrafish testis [23]. The undifferentiated gonad express amh at 17 and $21 \mathrm{dpf}$, with a male-biased expression starting at about $30 \mathrm{dpf}$ in zebrafish [24,25], suggesting that Amh is important in male zebrafish sex differentiation. Male-biased overexpression has also been shown in other species, like Japanese flounder (Paralichthys olivaceus) [26] and rainbow trout (Oncorhynchus mykiss) [27,28].

The dax1 gene (dosage sensitive sex-reversal adrenal hypoplasia critical region, chromosome $\mathrm{x}$, gene 1) codes for a nuclear receptor protein, that amongst others represses the transcription of steroidogenic factor 1 (Sf1) in mammals [29], which in turn regulates the expression of many steroidogenic enzymes and genes involved in reproduction [30]. Dax1 has an essential role in fetal testis development in mice [31], and Cyp19 aromatase expression is up-regulated when Dax1 is disrupted [32]. In contrast, over-expression of this gene caused male to female sex reversal in humans [33]. In fish the role of Dax1 is less clear.

Shp (short heterodimer partner) is a nuclear receptor protein that belongs to the same subfamily of nuclear receptors as Dax1. It functions as a transcriptional co-repressor that inhibits the expression of steroidogenic genes by inhibiting the expression of $s f 1$, thereby acting as a gonadal gatekeeper of male sexual maturation in mice [34]. The Shp protein might have similar functions in fish, as shp is highly expressed during early life stages in Nile tilapia (5 dph) and seemed to repress the activity of $s f 1$ [35]. Moreover, in rainbow trout, shp was highly expressed during early stages of sex differentiation, and then decreased twofold in both sexes [27].

Sox9 is a transcription factor containing the DNAbinding motif HMG, and is considered one of the more important genes related to sex differentiation in vertebrates [36]. In mammals, Sox9 has multiple functions such as cartilage formation and testis differentiation $[37,38]$. In zebrafish, two sox9 genes have been identified: $\operatorname{sox} 9 a$ and $\operatorname{sox} 9 b$ [39]. Sox9a may have a role in testis, and Sox9b may have a role in ovary development, based on expression patterns in adults. Hence, in zebrafish, $\operatorname{sox} 9 a$ may be male biased and $\operatorname{sox} 9 b$ may be female biased. However, both sox9a and sox9b are expressed in chondrogenic cells of both sexes [39]. A sexually dimorphic sox 9 expression pattern was also indicated in medaka and rainbow trout $[40,41]$.

Based on morphological studies, sex differentiation in Atlantic cod was initially reported to take place from approximately $27 \mathrm{~mm}$ total body length (TL) [42], and steroid treatment to induce masculinization was recommended from approximately $25 \mathrm{~mm}$ TL. But a more recent study demonstrated that exposure of Atlantic cod to 17- $\alpha$ methyltestosterone in the diet from $12 \mathrm{~mm}$ to $25 \mathrm{~mm} \mathrm{TL}$ onwards resulted in high proportion of hermaphrodites, suggesting that sex differentiation commenced earlier than at $27 \mathrm{~mm}$ TL [2]. We therefore wanted to carry out a combined morphological and molecular study on sex differentiation in Atlantic cod to study this process further.

We examined the morphological development of the early gonads in individuals from 14 to $34 \mathrm{~mm}$ TL. Moreover, in individuals from 12 to $49 \mathrm{~mm}$ TL we studied the expression of genes known to be involved in sex differentiation and early gonadal development in other teleosts species. Partial sequences of Atlantic cod $a m h$, dax1, shp and sox9 were obtained, specific real-time qPCR assays were developed and validated, and transcript levels were analyzed in the trunk (head and tail removed) of individuals from a normal, mixed sex population and from an all-female population produced with sperm from sex-reversed genetic females.

\section{Methods}

The following experiment was approved by the National Animal Research Authority in Norway in advance of the experiment.

\section{Fish material}

Origin: Three XX hermaphrodites (genotypic females) from a previous masculinization trial [2] and one $X Y$ male (genotypic male) were slaughtered, testis tissue was excised and carefully minced in separate sterile dishes, before dilution with Hanks Balanced Saline Solution 
(HBSS - modified; Sigma-Aldrich, St Louis, Missouri, USA) (3 ml milt/30 ml HBSS) and incubated on ice for $30 \mathrm{~min}$. Approximately $250 \mathrm{ml}$ of stripped eggs from two XX females were mixed and separated into 4 equal batches; three batches were fertilized with sperm from the three XX hermaphrodites, and one batch were fertilized with sperm from one normal XY male. The batches were incubated for $35 \mathrm{~min}$ before transfer into four separate $70 \mathrm{~L}$ incubators at ambient temperature $\left(6.2{ }^{\circ} \mathrm{C} \pm 0.1\right)$ and salinity $(35 \%)$. At four days post hatching (dph) (118.6 degree days) the larvae were transferred group-wise to start-feeding tanks $(50 \mathrm{~L})$ with a water temperature of $8.3{ }^{\circ} \mathrm{C}$, which was raised to $12{ }^{\circ} \mathrm{C}$ over the following 10 days $(14 \mathrm{dph})$. The tanks were supplied with algae paste and rotifers, and $33 \mathrm{dph}$ the larvae received artemia, and were gradually weaned onto dry feed from $36 \mathrm{dph}$. The weaning diet was a commercial agglomerated diet (Ewos Aglo norse, Bergen, Norway) with a particle size range of 300-500 $\mu \mathrm{m}$ (for fish between 9-14 mm total body length; TL), and of 400$600 \mu \mathrm{m}$ (for fish between 13-22 mm TL). All tanks were supplied with automatic feeders to ensure continuous feeding.

\section{Sampling}

For gene expression analysis, approximately 50 individuals were sampled from both the mixed sex population and one of the all-female populations at each of the following time points: 66, 74, 79, 87 and 96 days post fertilization ( $\mathrm{n}=500$ individuals). The average TL $( \pm$ SD) at each sampling was $11.2( \pm 2.4) ; 18.4( \pm 4.9) ; 23.9( \pm 3.6)$; $30.4( \pm 3.8)$ and $43.7( \pm 4.0) \mathrm{mm}$ respectively.

The fish were sedated in MS-222 (tricaine methanesulfonate, Finquel, Washinton, USA) $(0.013 \mathrm{~g} / 500 \mathrm{ml}$ chilled seawater $(\mathrm{SW}))$. TL was measured, and head and tail removed before the trunk was wrapped in prelabeled aluminum foil and snap frozen in liquid nitrogen. The tissue was kept at $-80{ }^{\circ} \mathrm{C}$ until analysis.

\section{RNA extraction and gene cloning}

Total RNA was isolated from mature Atlantic cod testis using Trizol reagent (Invitrogen, Carlsbad, California, USA) according to established procedures. The RNA amount was quantified (NanoDrop Technologies, Wilmington, DE, USA) and its quality checked by agarose gel electrophoresis. cDNA was subsequently generated using a SMART RACE cDNA kit (Clontech, Mountain View, California, USA), according to the manufacturer's instructions. Cloning of gene specific cDNA fragments was done by PCR using primers deduced from orthologous gene sequences or from sequence searches in an in-house expressed sequence tag (EST) database. All PCR primers are given in Table 1. The obtained
Table 1 Primers for cloning of $a m h$, dax $1, \operatorname{shp}$, sox $9 b$ and vasa in Atlantic cod

\begin{tabular}{|c|c|c|}
\hline Primer name & Direction & Primer sequence* \\
\hline amh_fw1 & forward & 5'-CGACCAGCAGGAGAGCTCCAGTACA -3' \\
\hline amh_rv2 & reverse & 5'-CATGTTTCCTTGACGTGGCTGAGG-3' \\
\hline dax1_fw1 & forward & $\begin{array}{l}\text { 5'-TGCAAAGCSGCSTCSSMRGTYCTGGYGA- } \\
\text { ARAC-3' }\end{array}$ \\
\hline dax1_rv2 & reverse & 5'-CCASCACGAGCARRGGYGCCCA-3' \\
\hline dax1_fw3 & forward & $\begin{array}{l}\text { 5'-GATACGCTTCGTGAAAAACGTGCCGTGT- } \\
\text { TाTCG-3' }\end{array}$ \\
\hline dax1_rv 4 & reverse & 5'-GACGACCAGCTGGTGCTCGTGCGGAGC-3' \\
\hline shp_fw1 & forward & $\begin{array}{l}\text { 5'-ACTITATGAAGAACTTGCCGGCGTTTAAC- } \\
\text { CAGCTG-3' }\end{array}$ \\
\hline shp_rv 2 & reverse & $\begin{array}{l}\text { 5'-CAGCGATCAGTTITCGCTGCTCCAGAAGT- } \\
\text { GCTG-3' }\end{array}$ \\
\hline sox9_fw1 & forward & 5'-GGCTACGACTGGACNYTNGTNCCNATG-3' \\
\hline sox9_rv2 & reverse & 5'-GGCAGGTACTGRTCRAACTCRTYGAC-3' \\
\hline vasa_fw1 & forward & 5'-GGTGTCAACTITGAYAARTAKGA-3' \\
\hline vasa_rv2 & reverse & 5'-CCGGTTCTACCAATKCGRTGNACRTA-3' \\
\hline
\end{tabular}

fragments were subcloned in pCR4-TOPO (Invitrogen, Carlsbad, California, USA) and sequenced.

An Atlantic cod amh sequence was obtained using primers amh_fw1 and amh_rv2 to generate a 387 base pairs (bp) long PCR fragment that was verified as $a m h$ by sequence similarity (Genbank accession no HQ630631). Primers for sox9 (sox9_fw1 and sox9_rv2) were predicted from an alignment of several fish sox 9 sequences and used for PCR amplification of a 653 bp long fragment that was verified by sequencing (Genbank accession no HQ630630). The sequence of vasa from tilapia, zebrafish and trout were aligned and used to predict primers vasa_fw1 and vasa_rv2. The primers produced a 1087 bp long fragment that was verified as vasa (Genbank accession no HQ630632). To clone a partial cod dax 1 cDNA sequence, degenerate primers dax1_fw1 and dax1_rv2 were designed, and PCR products of $\sim 160$ bp were sub-cloned and sequenced. Two different sequences were obtained: one sequence was highly similar to $\operatorname{dax} 1$, whereas the other sequence was highly similar to shp sequences. To obtain additional cod dax1 cDNA sequences, specific primers dax1_fw3 and dax1_rv4 were designed and used for $3{ }^{\prime}$-RACE in combination with the UPM and NUP primers, respectively (supplied in the SMART RACE kit; Clontech, California, USA), using 3'RACE-ready mature cod testis cDNA as template. PCR products of $\sim 900 \mathrm{bp}$ were generated, gel purified with QIAEX, TOPO cloned and sequenced (Genbank accession no HQ677835). In a similar way, specific primers shp_fw1 and shp_rv2 were designed to obtain additional cod shp cDNA sequences with 3'-RACE. Approximately 675 bp PCR products were generated, gel 
purified with QIAEX, TOPO cloned and sequenced (Genbank accession no HQ677836).

The cloning and development of real-time PCR assay of Atlantic cod cyp19a1a has been reported earlier (as cyp19a1) [43].

\section{Real time quantitative PCR (qPCR)}

In order to obtain gene expression profiles from individual larvae, total RNA were isolated from frozen larvae trunks $\left(-80{ }^{\circ} \mathrm{C}\right)$ using an Invitrogen iPrep ${ }^{\mathrm{TM}}$ Purification Instrument (Invitrogen,Carlsbad, California, USA) and the IPrep ${ }^{\mathrm{TM}}$ Trizol ${ }^{\circledR}$ PLUS RNA Kit (Invitrogen, Carlsbad, California, USA) according to the manufacturer's instructions. Homogenization of the tissue was performed using $2 \mathrm{ml}$ tubes containing zirconium oxide beads in a Precellys ${ }^{\circledR} 24$ Homogenizer (Bertin, Villeurbanne, France).

RNA quantity and quality were determined by UV absorbance at 230, 260 and $280 \mathrm{~nm}$ using a NanoDrop ${ }^{\circledR}$ NP-1000 spectrophotometer (NanoDrop technologies, Wilmington, DE, USA). Samples with a 260/280 nm absorbance ratio outside the range of $1.7-2.1$ were excluded from further analysis. On a subset of the samples (approximately 10\%), RNA integrity was verified with a Bioanalyzer 2100 expert system (Agilent Technologies Inc., Santa Clara, USA) and all samples had RIN values from 8-10. Reverse transcription into cDNA took place using a reverse transcription core kit (RT-RTCK-05, Eurogentec, Searing, Belgium) according to the manufacturer's instructions with $500 \mathrm{ng}$ total RNA in $30 \mu \mathrm{l}$ reaction volume. The cDNA was diluted 10 -fold with nuclease free water.

Specific primers and probes for real-time, quantitative PCR analysis of Atlantic cod amh, cyp19a1a, dax1, shp, and sox $9 b$ mRNAs as well as for the reference gene efl $\alpha$ are given in Table 1. They were all designed with Primer express software (Applied Biosystems, Carlsbad, California, USA), according to the manufacturer's guidelines.

TaqMan PCR assays were performed in duplicate, using 96-well optical plates on an ABI Prism Fast 7900HT Sequence Detection System (Applied Biosystems, Carlsbad,CA, USA) using default settings $\left(95^{\circ} \mathrm{C}\right.$ for 20s, followed by a 40 cyckles of $95{ }^{\circ} \mathrm{C}$ for $1 \mathrm{~s}$ and $60{ }^{\circ} \mathrm{C}$ for $\left.20 \mathrm{~s}\right)$. For each $25 \mu \mathrm{l}$ PCR reaction $2.5 \mu \mathrm{l}$ cDNA was mixed with $200 \mathrm{nM}$ fluorogenic probe, $900 \mathrm{nM}$ sense primer, $900 \mathrm{nM}$ antisense primer in 1xTaqMan Fast Universal PCR Master Mix (Applied Biosystems, Carlsbad, California, USA). Gene expression data were calculated relative to the smallest and youngest fish, using the $\Delta \Delta \mathrm{Ct}$ method as described in detail previously [44].

\section{Gonad histology}

For the evaluation of gonad histology, Atlantic cod ranging from 14 to $34 \mathrm{~mm}$ TL were obtained from a commercial hatchery (Sagafjords, Bergen, Norway). These fish were reared under the same temperature and feeding regime and exhibiting growth rates comparable to the fish used for the gene expression experiment. The fish were sedated as described above, the length was measured, and the fish were euthanized with MS-222 (tricaine methanesulfonate, Finquel, Washinton, USA) (0.04 g/ $500 \mathrm{ml} \mathrm{SW}$ ). The juveniles were individually fixed either in $5 \% \mathrm{v} / \mathrm{v}$ PBS-buffered glutaraldehyde, or in $4 \% \mathrm{w} / \mathrm{v}$ (RNase-free) PBS-buffered paraformaldehyde at $4^{0} \mathrm{C}$ overnight. After dehydration, the glutaraldehyde-fixed samples were embedded in Technovit 7100 resin (Heraus Kultzer Wehrheim, Germany) while the paraformaldehydefixed samples were embedded in RNase-free paraffin (Histowax $56.58{ }^{\circ} \mathrm{C}$, VWR International, Norway), according to conventional techniques. Serial longitudinal sections of 2 (plastic embedded) or 4 (paraffin embedded) $\mu \mathrm{m}$ thickness were collected and mounted consecutively on glass slides. Some individuals were transversally embedded and sectioned; for this purpose they were first decalcified - by immersion in $80 \%$ formic acid at $40^{\circ} \mathrm{C}$ during $48 \mathrm{~h}-$ for facilitating sectioning. The serial histological sections were stained with $1 \% \mathrm{w} / \mathrm{v}$ toluidine blue $2 \% \mathrm{w} / \mathrm{v}$ borax staining solution. Each gonad was analyzed

Table 2 Primers and Probes for qPCR and ISH

\begin{tabular}{|c|c|c|}
\hline Transcript & Primer or probe & Sequence $\left(5^{\prime}-3^{\prime}\right)$ \\
\hline \multirow[t]{3}{*}{$a m h$} & forward primer & GTCAGGCCAGCGAGAGCA \\
\hline & reverse primer & AGGGCGACAACACATACGTTTC \\
\hline & probe & $\begin{array}{l}\text { [FAM]-CATCTGCAGGTGCAGGA- } \\
\text { ACACTATATGC-[TAMRA] }\end{array}$ \\
\hline \multirow[t]{3}{*}{ cyp19a1a } & forward primer & ACAACAACAAGTACGGCAGCAT \\
\hline & reverse primer & GTAGAGGAGCTGCTGAGGATGAG \\
\hline & probe & [FAM]-CGGCGTATGGATCAA-[MGB] \\
\hline \multirow[t]{3}{*}{ efiá } & forward primer & GCCCCTCCAGGACGTCTAC \\
\hline & reverse primer & ACGGCCCACGGGTACTGT \\
\hline & probe & [FAM]-AGATCGGCGGTATTG-[MGB] \\
\hline \multirow[t]{3}{*}{ daxi } & forward primer & TGGTGGCGCAGCTCTTCT \\
\hline & reverse primer & GCAGCACCTCTTCCATGTTGA \\
\hline & probe & $\begin{array}{l}\text { [FAM]-CAAGCCCGTGATCGGCG- } \\
\text { CC-[TAMRA] }\end{array}$ \\
\hline \multirow[t]{3}{*}{ shp } & forward primer & GCGGGCGTCGGTAAACTTA \\
\hline & reverse primer & CGCGTACTCCTTCGGACTCA \\
\hline & probe & $\begin{array}{l}\text { [FAM]- CAAACCGCCAAACCTCTTG- } \\
\text { AGACAGGGCCAAAC -[TAMRA] }\end{array}$ \\
\hline \multirow[t]{3}{*}{ sox9b } & forward primer & AAGAAGCCGAGCGCTTAAGG \\
\hline & reverse primer & CCGCCTCGGTTGGTATITG \\
\hline & probe & $\begin{array}{l}\text { [FAM]-TTCAACACAAAAAGGACCA- } \\
\text { CCCGGACT-[TAMRA] }\end{array}$ \\
\hline \multirow[t]{2}{*}{ vasa } & forward primer & $\begin{array}{l}\text { T3Rpps- TGACCTGGACCAGCTTCT- } \\
\text { GCTCCACGTCA }\end{array}$ \\
\hline & reverse primer & $\begin{array}{l}\text { T7Rpps- CAAGTTTGCTCATGGGAC- } \\
\text { CTGCGTGCGT }\end{array}$ \\
\hline
\end{tabular}


according to morphological features, such as shape, presence, size and number of germ cells and presence of an ovarian cavity.

In eight individuals (14 to $20 \mathrm{~mm} \mathrm{TL}$ ), the total number of germ cells was quantified in plastic embedded serial sections. The length of the gonad was measured by summing up the total number of sections $(2 \mu \mathrm{m})$ in which gonad tissue was observed. For estimating germ cell number per gonad, the diameter of germ cell nuclei was determined in 8 juveniles using an ocular with a scale bar. Based on the germ cells' average diameter $(7.1 \pm 0.04 \mu \mathrm{m} ; \mathrm{n} \sim 20 /$ juvenile), germ cells were counted in every third section of $2 \mu \mathrm{m}$, to avoid double counting.

In order to visualize germ cells, vasa mRNA was detected by in situ hybridization. A cod vasa PCR product (405 bp) was generated using primers vasa_ISH1 and vasa_ISH2 (Table 2) and cod testis cDNA as template. The PCR product was gel purified and $300 \mathrm{ng}$ served as template for digoxigenin (DIG)-labeled cRNA probe synthesis by in vitro transcription (Roche Molecular Biochemicals) according to the manufacturer's instructions.

For vasa in situ hybridization, RNase-free paraformaldehyde fixed, paraffin (Histowax $56.58{ }^{\circ} \mathrm{C}$, VWR
Interantional, Norway) embedded individuals were used, as described in [45], using sense and antisense cRNA probes at a concentration of $200 \mathrm{ng} / \mathrm{ml}$ of hybridization buffer. Ribonuclease A $(2 \mu \mathrm{g} / \mathrm{ml}$; Sigma-Aldrich, St. Louis, USA) treatment was performed in RNase buffer $(0.01 \mathrm{M}$ Tris, $0.5 \mathrm{M} \mathrm{NaCl}, 0.005 \mathrm{M}$ edetic acid [EDTA], pH 7.5). As positive control, the same procedure for vasa mRNA in situ hybridization was performed on sections of mature cod testis.

\section{Statistics}

The germ cell number (per gonad) and gonad length $(\mu \mathrm{m})$ were tested for statistical differences using a nonparametric Mann-Whitney $U$ test $(p<0.05)$ (Statistica 9, StatSoft inc. Tulsa, USA).

\section{Results}

Gonadal histology and germ cell morphometry

In juvenile Atlantic cod, gonad tissue is located in the dorso-caudal region of the abdominal cavity, ventral of the swim bladder (Figures 1a and 2a), and connected to the dorsal body wall by a thin connective tissue, the mesogonadium. In individuals between 14 to $18 \mathrm{~mm} \mathrm{TL}$, the gonads consisted of connective tissue, small blood
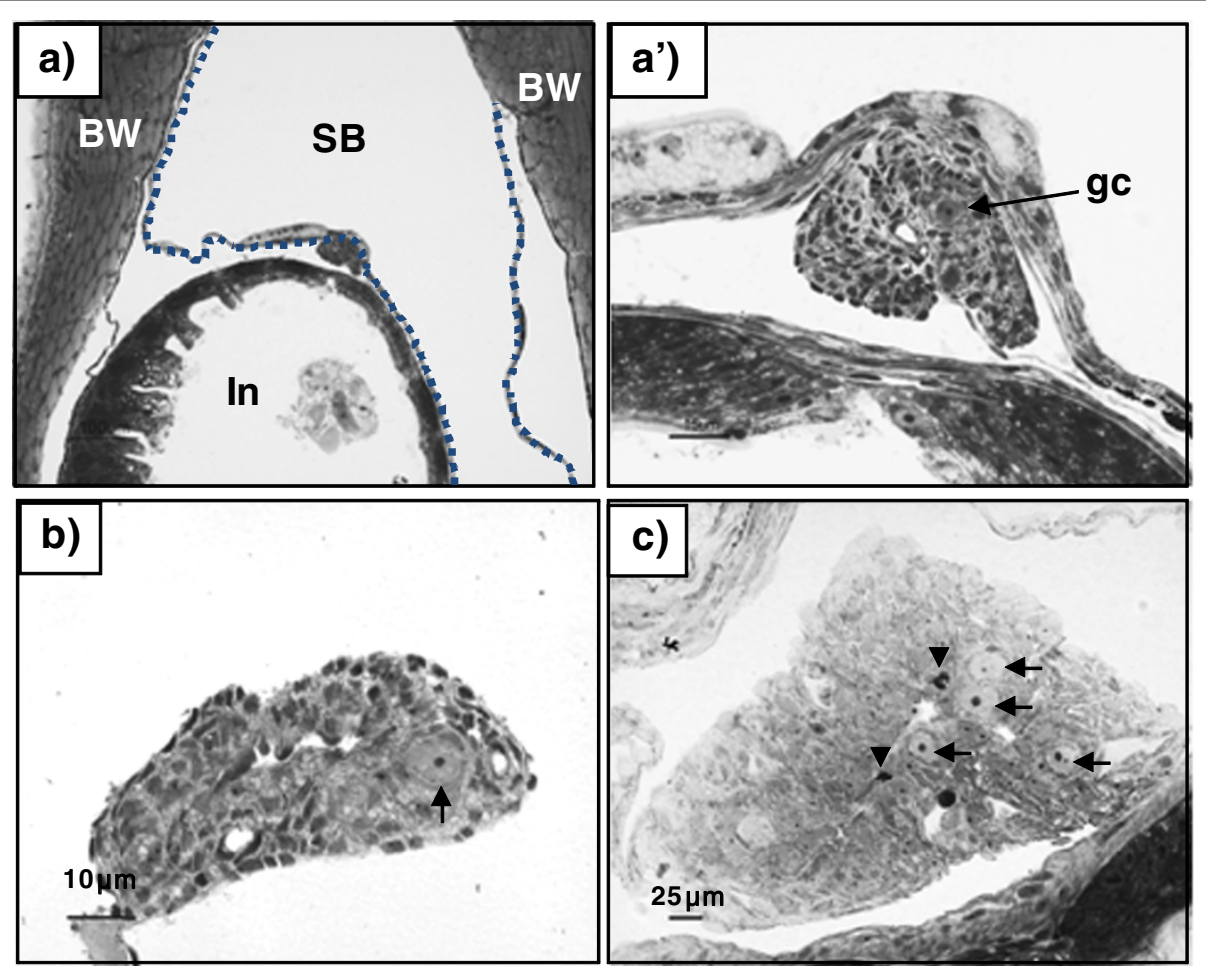

Figure 1 Differentiating gonad of Atlantic cod, presumptive female. Transverse plastic section $(2 \mu \mathrm{m})$ stained with Toluidine blue/Borax solution. a) and $\mathbf{a}^{\prime}$ ) formation of an ovarian cavity in a $16 \mathrm{~mm}$ TL juvenile. a): scale bar represents $100 \mu \mathrm{m}$; a'): scale bar represents $15 \mu \mathrm{m}$ ); b) gonad with an ovarian cavity in a $18 \mathrm{~mm}$ TL juvenile; c) ovary in a $30 \mathrm{~mm}$ TL juvenile. SB - swim bladder; In - intestine; BW - body wall; gc - germ cell. The stippled line identifies the ventral part of the swimming bladder in a). Arrows indicate primordial germ cells; arrowheads in c) indicate mitotic figures. 

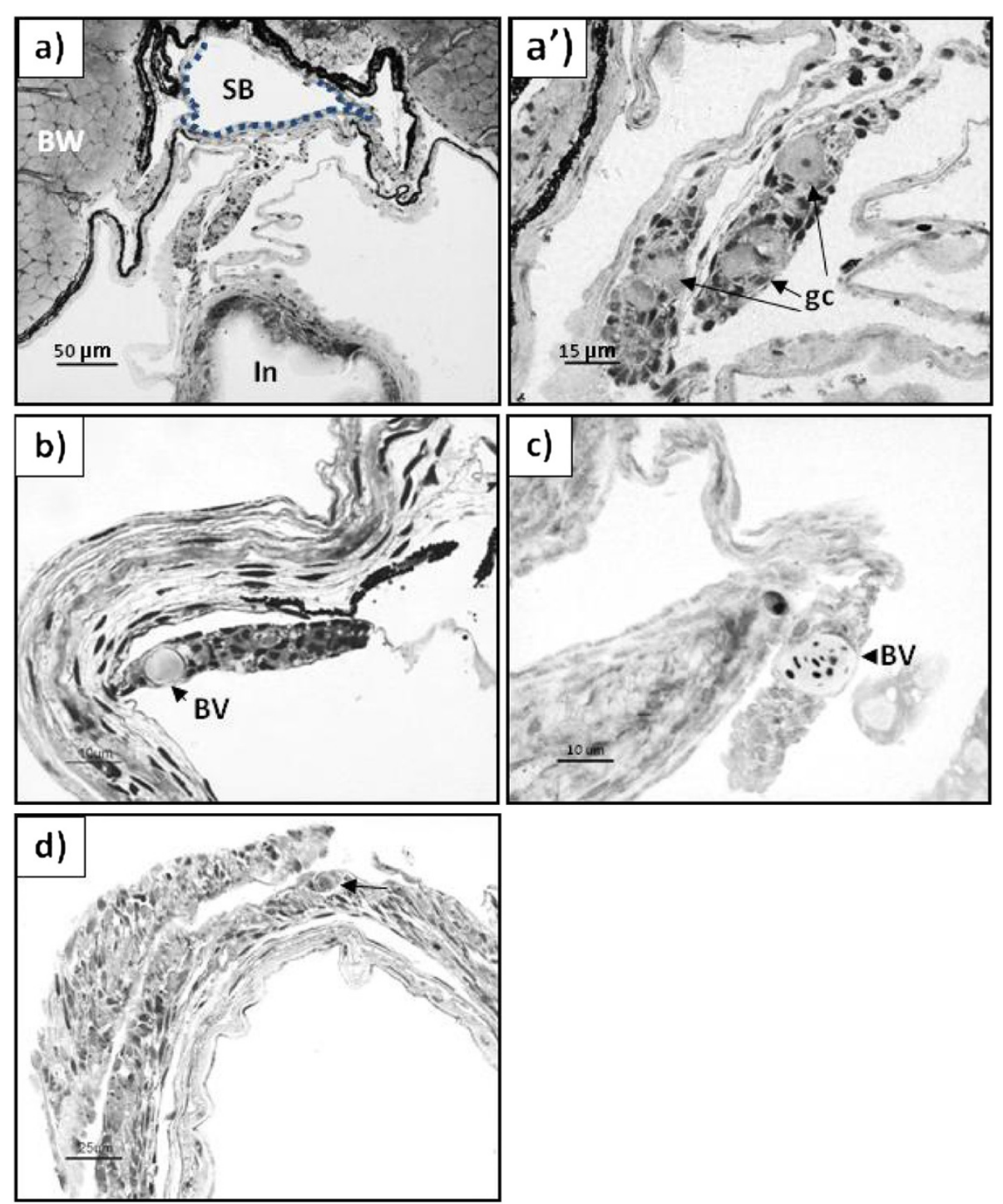

Figure 2 Differentiating gonad of Atlantic cod, presumptive male. Transverse plastic section $(2 \mu \mathrm{m})$ stained with Toluidine blue/Borax solution. a) and $\mathbf{a}^{\prime}$ ) Undifferentiated gonad in a $14 \mathrm{~mm}$ TL juvenile; b) Early testis in a $18 \mathrm{~mm}$ juvenile (scale bar represents $10 \mu$ ); c) Early testis in a $34 \mathrm{~mm}$ juvenile (scale bar represents $10 \mu \mathrm{m}$ ); d) Testis of a $32 \mathrm{~mm}$ juvenile (scale bar represents $25 \mu \mathrm{m}$ ). BV - blood vessel; arrows indicate primordial germ cells.

vessels and large germ cells $(7.1 \pm 0.04 \mu \mathrm{m}$ diameter $)$, with no apparent difference between individuals as regards somatic elements and germ cell morphology (Figures 1a' and $\left.2 a^{\prime}\right)$. A more detailed analysis on a subsample of eight individuals between 14-20 mm TL, revealed that the total number of germ cells per gonad and the gonad size was either high or low (Figure 3). Moreover, the group with the high number of germ cells showed several mitotic figures in the germ cells and a large gonad size, while the group with few germ cells also showed few mitotic figures in the germ cells and small gonads.

Histological examination of gonadal development in individuals in the size range $18-20 \mathrm{~mm}$ TL revealed the first signs of ovarian cavity formation in five of the examined individuals: gonadal somatic tissue started to grow out laterally (Figure 1a and 1a'), arched back to the gonad, and eventually fused in a zipper-like pattern. The fusion progressed rostrocaudally, creating the ovarian cavity in the stroma of the forming ovaries (Figure 1a and 1b). In similarly sized fish without signs of ovarian cavity formation, a large blood vessel was observed in the proximal region of the gonad (Figure $2 \mathrm{~b}$ and $2 \mathrm{c}$ ); lateral outgrowths were absent. From $20 \mathrm{~mm}$ TL onwards, the gonads grew considerably, resulting in an enlargement of the ovarian cavity concomitant with an increase in 


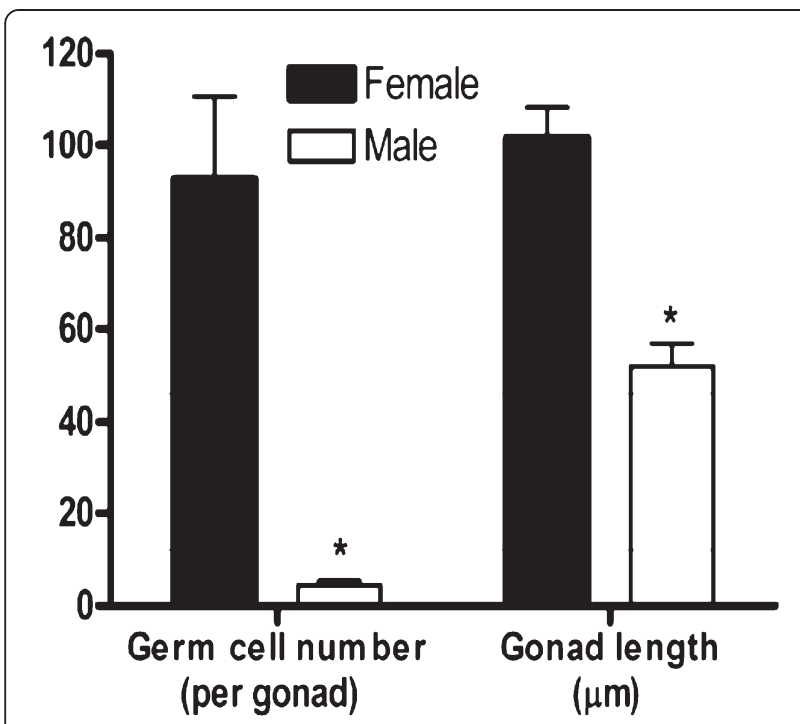

Figure 3 Number of germ cells per gonad. Total number of germ cells per gonad and gonad length of Atlantic cod juveniles $(n=8)$ ranging between 14 to $20 \mathrm{~mm}$ TL. Asterisks denote significant difference, $P<0.05$ (Man-Whitney non-parametric test).

the number of germ cells in the ovaries, while an elongation of the gonad was seen in presumptive males (Figures $1 \mathrm{c}$ and $2 \mathrm{~d}$ respectively).

\section{In situ hybridization}

To identify and verify the presence of germ cells in the developing gonads with an independent approach, we performed in situ hybridization for vasa mRNA. The signal for vasa was very strong in the germ cells in all gonads of individuals up to $34 \mathrm{~mm}$ TL (Figure 4a and $4 \mathrm{~b}$ ). Maturing testis was used as a positive control (Figure 4c). Expression of vasa was strong in spermatogonia, weak in spermatocytes, and absent in spermatids and spermatozoa. No signal was observed in sections incubated with the sense probe (Figure $4 \mathrm{~d}$ ).

\section{Gene expression during sex differentiation}

Throughout most of the sampling period $(12-40 \mathrm{~mm}$ $\mathrm{TL}$ ), the expression of cyp19a1a mRNA was higher in the all-female population and in approximately half of the individuals of the mixed sex population, compared to the other half of the individuals of the mixed sex population (Figure 5a). However, an increase was observed in cyp19a1a mRNA expression from around 30-35 mm TL, which started from different levels in the two subgroups of the mixed sex group.

The transcript levels of amh showed no bimodality until around $20 \mathrm{~mm} \mathrm{TL}$, and the mixed sex group and the all female group had overlapping values in that size range, while an apparent bimodal pattern was evident from $20 \mathrm{~mm}$ TL onwards in the mixed sex group. From around $30-35 \mathrm{~mm}$
TL increasing levels were seen in both modals of the mixed sex group, and in the all female group (Figure $5 b$ ).

dax 1 mRNA levels showed a size dependent pattern (Figure 5c). All individuals exhibited low levels with some variation until approximately $30-35 \mathrm{~mm} \mathrm{TL}$, after which a up-regulation of dax1 mRNA levels was recorded in all individuals. The mRNA levels of shp also changed with the size but displayed a pattern opposite to that of dax1: up to $30-35 \mathrm{~mm} \mathrm{TL}$, levels were high but then declined (Figure $5 \mathrm{~d}$ ).

The expression of sox $9 b$ showed a gradual twofold increase with size (see Additional file 1: Figure S1), Expression levels of the reference gene ef $1 \alpha$ were relatively stable throughout the sampling period for all individuals (see Additional file 2: Figure S2).

\section{Discussion}

In Atlantic cod, the undifferentiated gonad is positioned ventral of the swim bladder in the caudal part of the body cavity, has very few germ cells and was observed in juveniles ranging from 14 to $18 \mathrm{~mm}$ TL. The first morphological sign of ovarian differentiation was observed in individuals of 18 to $20 \mathrm{~mm} \mathrm{TL}$, when an empty space formed in the stroma of the ovaries, known as the ovarian cavity. In the majority of gonochoristic teleosts examined, the appearance of an ovarian cavity is the earliest morphological sign of ovary formation [9].

In the size range of 14-20 mm TL, two subgroups were found that differed in germ cell number and gonad size, indicating ongoing morphological sex differentiation during this period. A common early distinction between ovary and testis is based on the number of germ cells present in the early gonad, since oogonia generally show earlier elevated mitotic activity and enter earlier into meiosis than spermatogonia [46]. The somatic part of the gonads appeared to be histologically undifferentiated until $18 \mathrm{~mm}$ TL in all individuals examined. Taken together, our morphological observations support the notion that individuals with a high number of germ cells before ovarian cavity formation were females whereas those with a low germ cell number most likely were males. These findings are in line with the observation of high mitotic activity of germ cells in developing ovaries of many teleost species [9]. In a more recent work on three-spined stickleback (Gasterosteus aculeatus), an increase in the number of germ cells in gonads of female but not of male fry preceded the appearance of traditional morphological criteria for sex differentiation [47].

In the current study, based on these considerations, individuals in the size range of $18-34 \mathrm{~mm}$ TL with no apparent ovarian cavity and a low number of germ cells were considered to be males. These presumptive males had small filament-shaped gonads, with few undifferentiated germ cells, but with large blood vessels in the 

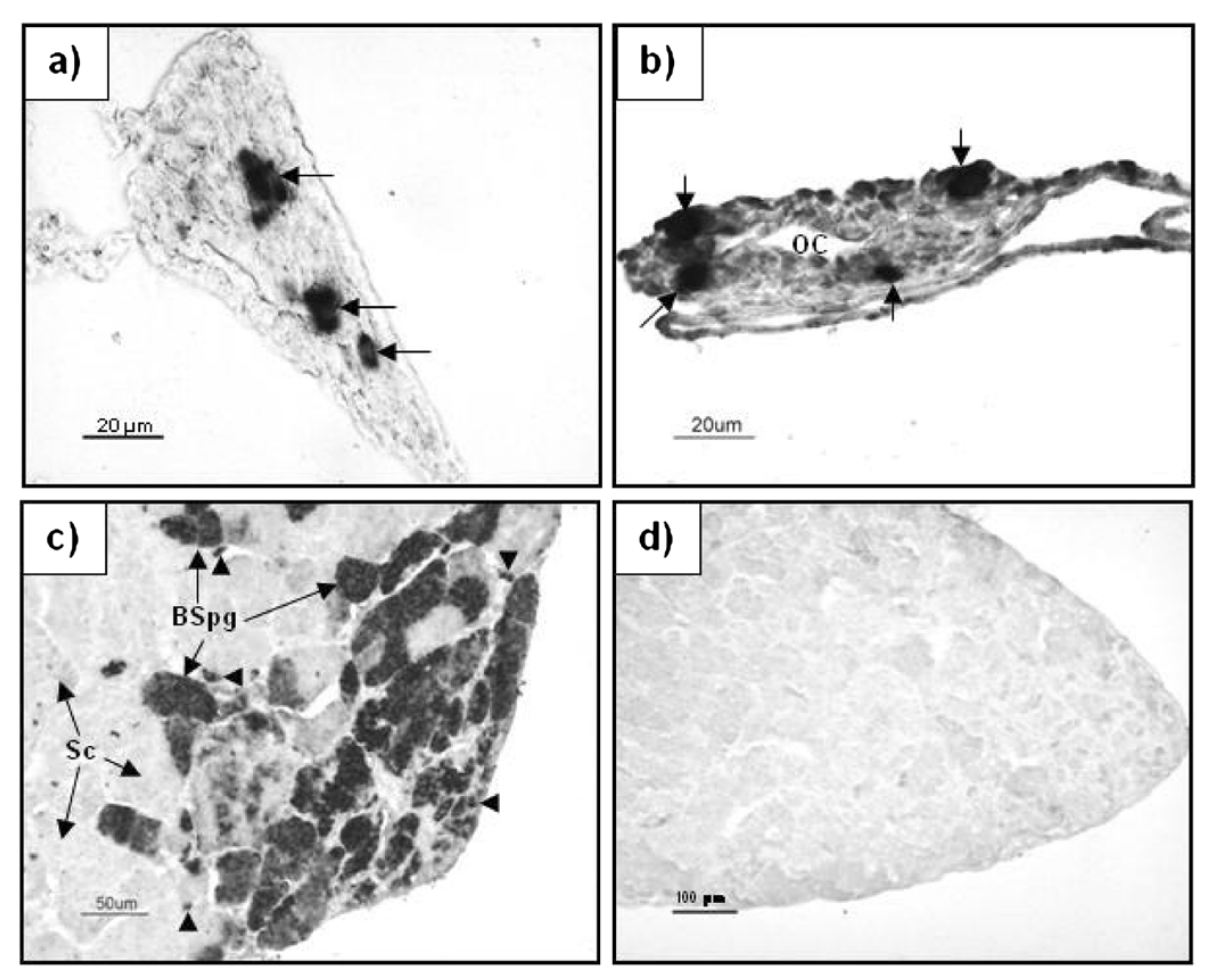

Figure 4 In situ hybridization for vasa mRNA in Atlantic cod gonads. a) Testis tissue of a fish of $34 \mathrm{~mm}$ TL; b) ovarian tissue of a fish of $32 \mathrm{~mm}$ TL, OC - ovarian cavity; c) In a mature (adult) testis (positive control); d) In a maturing testis using sense probe (negative control). Arrows indicate positive oogonia/spermatogonia in a) and b); arrowheads show type A spermatogonia in C, BSpg - type B spermatogonia; Sc - spermatocytes.

proximal region of the gonad. The formation of blood vessels at the proximal or distal regions of the gonad is considered an indicator of the early testis in several fish species $[46,48]$.

Despite differences in germ cell numbers between presumptive males and females in the size range of 14$20 \mathrm{~mm}$ TL, further germ cell differentiation was not observed, indicating that the somatic differentiation of ovaries in individuals of approximately $18-20 \mathrm{~mm} \mathrm{TL}$ preceded germ cell differentiation, except for their increased proliferation in females. This is in accordance with the conclusions of Nakamura et al. [46], where morphological differences in the stroma may give a more correct indication of the timing of the sex differentiation than germ cell morphology.

To confirm the identity of the germ cells, we performed vasa in situ hybridization as vasa mRNA is restricted to germ cells [49-51]. In individuals of 32-34 mm TL, we observed a very strong vasa signal in the germ cells.

Our results confirmed that Atlantic cod is a differentiated gonochoristic species, where the sexually undifferentiated gonad develops directly into a testis or an ovary [42]. Our study provides evidence that morphological gonad differentiation in Atlantic cod occurs earlier in females than in males, as generally found in other primary gonochoristic teleosts [5,9]. Different from the results presented here, an earlier report described ovarian cavity formation in Atlantic cod at $27 \mathrm{~mm}$ TL [42]. This divergence might be related to significant growth differences between the two studies.

Our use of an all-female population compared with a normal mixed sex population allowed studying potential sexually dimorphic gene expression patterns during the period of sex differentiation. During the period from 12-20 mm TL, cyp19a1a appeared to have a sexually dimorphic expression pattern in the mixed-sex population in parallel with the observed morphological female sex differentiation. The all-female population displayed a relatively high and less variable cyp19a1a expression in this size range, corresponding to the levels of the highest modal of the mixed sex group.

A bimodal expression pattern of cyp19a1a was apparent already from 12-14 mm TL in the mixed-sex group, suggesting that molecular sex differentiation already commenced in this size range before morphological indications of female sex differentiation. In a similar manner, a sexually dimorphic pattern in the expression of cyp19a1b in the brain of rainbow trout populations before and during the early morphological gonad differentiation has been reported [27,52]. 


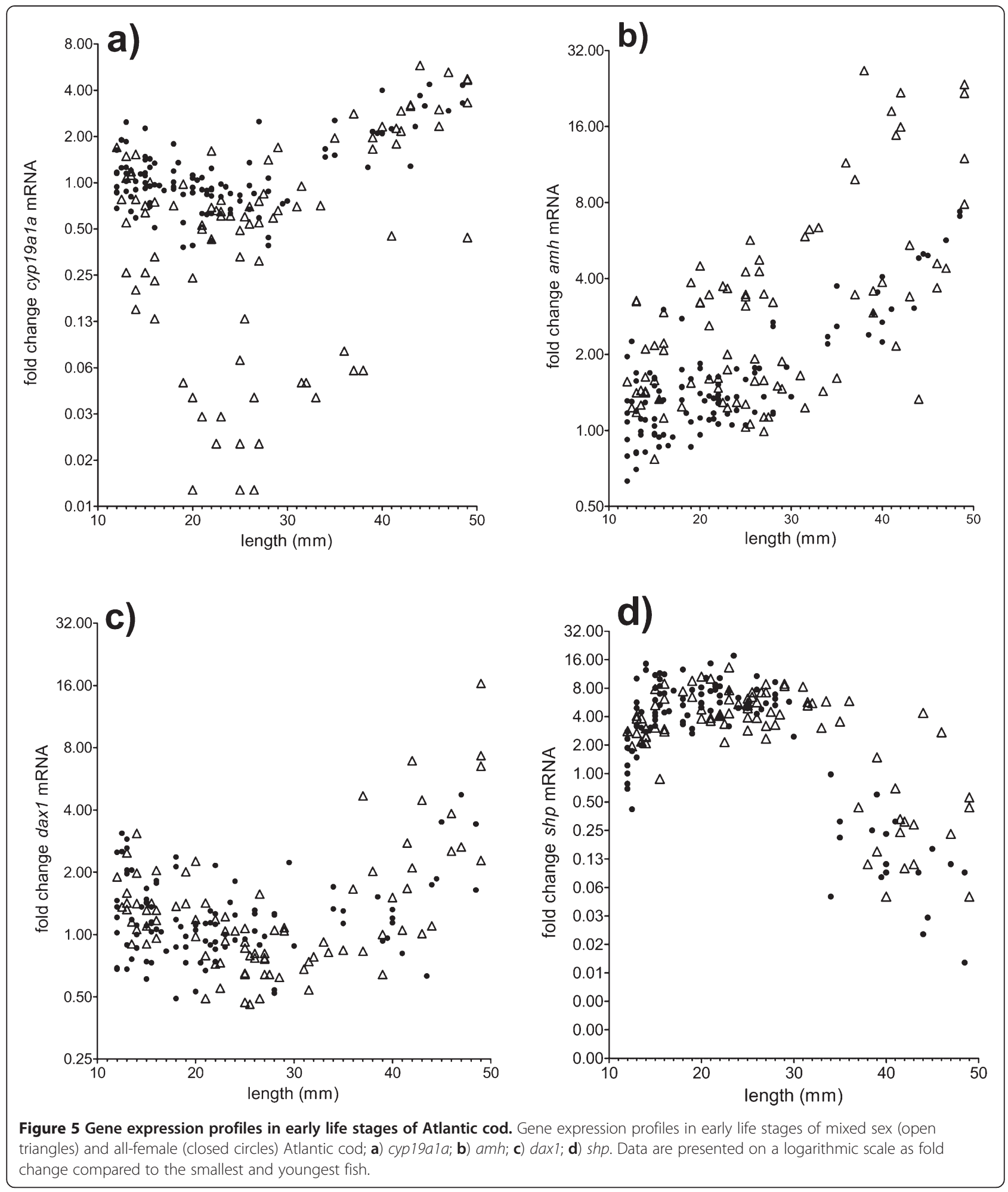

From around $30-35 \mathrm{~mm}$ TL onwards, an increasing cyp19a1a expression was observed both in the presumptive females and presumptive males, as well as in the all-female population. This may indicate that Cyp19a1a also has a role in male development in this size range, and may be related to up-regulation of steroidogenesis in both sexes.

In the size interval from $12-20 \mathrm{~mm}$ TL, no sexually dimorphic expression pattern was evident for amh. However, from around $20 \mathrm{~mm} \mathrm{TL}$ until the end of 
the experiment, amh displayed an apparent sexually dimorphic expression pattern, as indicated by low transcript levels in the all-female population and the bimodal pattern in the mixed sex group. This pattern suggests a role for Amh in testis differentiation starting from $20 \mathrm{~mm}$ TL onwards.

The further increase of amh mRNA observed after $30 \mathrm{~mm}$ TL together with increasing cyp19a1a mRNA levels in the presumptive males may be related to a possible function of aromatase and estrogens in stimulating stem cell proliferation, while increased amh mRNA levels may at the same time have prevented the onset of spermatogenesis as shown in Japanese eel (Anguilla japonica) [53,54]. Furthermore, in the all-female population and the presumptive females of the mixed sex population, there was a gradual increase of $a m h$ mRNA levels from around $35 \mathrm{~mm}$ TL onwards, although at lower levels than in the presumptive males, suggesting a role for amh also in females. This is corroborated by the finding that $a m h$ is expressed in granulosa cells in zebrafish [24].

dax 1 and shp did not show an apparent sexually dimorphic pattern in our study. However, a size dependent pattern was evident, with a low expression of dax1 from the first samples at $12 \mathrm{~mm}$ TL, which persisted until approximately $35 \mathrm{~mm} \mathrm{TL}$, when dax 1 expression increased in most individuals. The opposite was true for $s h p$, which was expressed initially at high levels, with a drop to low expression level after approximately $35 \mathrm{~mm}$ TL. One possible reason for the lack of an apparent sexually dimorphic expression of $d a x 1$ may be that this gene is also expressed in many other tissues apart from the gonads [35,55], which may mask potential sex-dimorphic expression in the gonads. In Nile tilapia, dax 1 and $s h p$ showed no sexually dimorphic expression during sex differentiation, and the expression of dax1 was weak in the early stages (5-10dph)) and then significantly up-regulated between 10-15 dph [35].

The high initial levels of $\operatorname{sh} p$ found here, followed by a drop to low expression levels after approximately $35 \mathrm{~mm}$ $\mathrm{TL}$, are consistent with findings in rainbow trout [27], where shp was found to belong to a group of genes showing high expression during early ovarian and testicular development, but decreasing in both sexes when gonads had differentiated and gametogenesis was about to commence. This decrease in shp transcript levels during/after sex differentiation may reflect that Shp-mediated repression of other hormone receptors might fade with completion of sex differentiation. Moreover, Shp suppressed the expression of steroidogenic enzymes in mouse Leydig cells [34], thus increasing cyp19a1a and decreasing shp are consistent with increased steroidogenic activity, also in the presumptive males after around $35 \mathrm{~mm}$ TL.

A phylogenetic analysis of teleost sox9 sequences deposited in the NCBI databank together with Atlantic cod sequences (Additional file 3: Figure S3) obtained from the recent genome sequence [56], revealed two subtypes that both are clearly distinct from sox8, similar to the situation in other teleosts such as zebrafish [39], medaka [42] and rainbow trout [43]. The Atlantic cod sox9 transcript studied in this communication is a $s o x 9 b$ variant, although the classification is somewhat unclear due to variable naming among the databank entries. The two sox9 variants are probably co-orthologues that are partially subfunctionalized [42], but possibly with species-specific expression pattern in gonads as indicated in medaka and zebrafish $[39,42]$.

The sox 9 variant that was analysed in the current study was thus classified as $s o x 9 b$, and was found to have

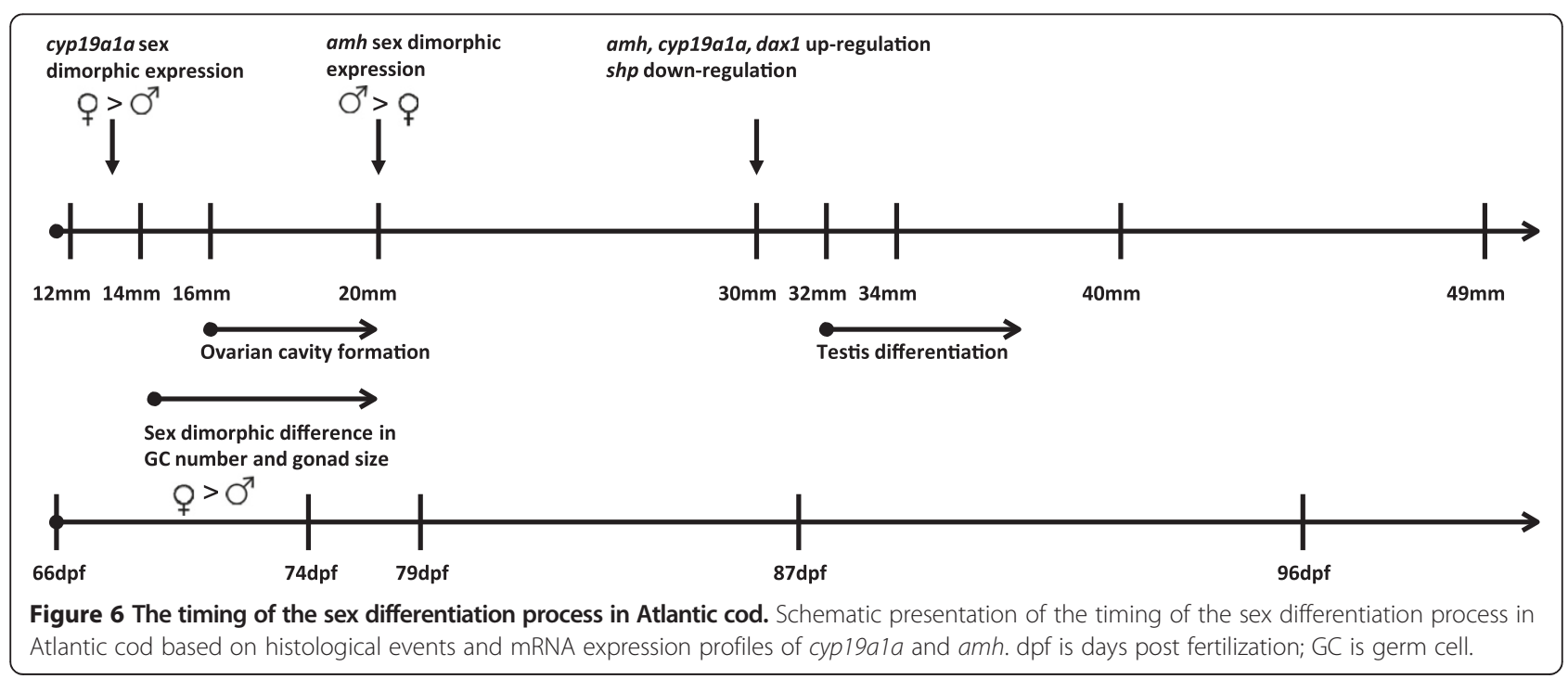


no sexually dimorphic pattern between $12-49 \mathrm{~mm}$ TL. However, there was a gradual increase in the expression of this gene throughout the sampling period. This was also the case in tilapia during sex differentiation [19], but in this species, sox9 was up-regulated in male gonads after sex differentiation. In our experiment, a possible explanation for the lack of male specific expression of $s o x 9 b$ could be that the use of the whole trunk may have masked any sexually dimorphic expression pattern in the gonads, since Sox 9 is also an important gene for cartilage development [39]. At this stage, there will be a substantial cartilage development due to high growth rates in general.

\section{Conclusions}

Our results suggest that sex differentiation in Atlantic cod has already commenced at around $12 \mathrm{~mm} \mathrm{TL}$, resulting in a sex-dimorphic expression pattern of cyp19a1a. From $14 \mathrm{~mm} \mathrm{TL}$, there was a difference in the proliferation of germ cells and in gonad size in presumptive females. The expression profiles of amh suggest that male differentiation commenced at approximately $20 \mathrm{~mm}$ TL, but apart from the large blood vessel at the proximal region of the gonad, testicular differentiation was not morphologically evident until later. At around 34-35 mm TL, there was a change in the expression profiles of cyp19a1a, amh, dax1 and shp. The increase of cyp19a1a, amh, dax 1 and the decrease of shp are compatible with up-regulation of genes encoding nuclear receptors and steroidogenic genes in males, possibly in context with estrogen-mediated expansion of the spermatogonial stem cell population. The main findings are schematically summarized in Figure 6.

Overall, the data suggest that treatments to masculinize Atlantic cod should commence before $18 \mathrm{~mm}$ TL, when the first morphological signs of female development were noted, and possibly as early as $12 \mathrm{~mm} \mathrm{TL}$, or earlier, as the first molecular signs of sex dimorphic development were noted from the start of the experiment. A body size of $12 \mathrm{~mm}$ TL correspond to the time when Atlantic cod normally are weaned from live prey diet to formulated feed, and thus a time when androgens or other compounds can easily by administered in a controlled manner. Application of e.g. androgens or aromatase inhibitor treatments before this body size would normally imply treatment in water which can be more difficult to control in terms of dosage and uptake. The suggested time window for androgen treatment as suggested in the current paper is supported by a recent study in Atlantic cod [2]. The study revealed that androgen treatments starting at $12 \mathrm{~mm}$ TL and lasting until $25 \mathrm{~mm}$ TL were very efficient in inducing sex reversal resulting in high proportions of hermaphrodites, while the same treatments in the size range of 12 to $20 \mathrm{~mm}$ TL were less effective, and treatments in the size range of 12 to $16 \mathrm{~mm}$ TL was not effective at all [2]. This suggests that the androgen treatment must cover the entire period when female differentiation was noted in the current study to be efficient in inducing sex reversal.

\section{Additional files}

\begin{abstract}
Additional file 1: Figure S1. Gene expression profiles of sox9b in early life stages of mixed sex (open triangles) and all-female (closed circles) Atlantic cod. Data are presented on a logarithmic scale as fold change in mRNA compared to the smallest and youngest fish.

Additional file 2: Figure S2. Scatter plot of $C_{t}$ values for effa mRNA from the mixed sex (open triangles) and all-female (closed circles) Atlantic cod individuals. Data are from quantitative real time PCR. All samples had similar template RNA concentrations loaded into the qPCR reaction.

Additional file 3: Figure S3. Phylogenetic analysis of Sox9 amino acid sequences from different teleost species depicted as trees generated by the Neighbor-Joining (NJ) method (left) and Maximum Likelihood (ML) method (right). The bar represents 5\% divergence between sequences. The sequences group into two large classes as noted as $a$ and $b$ to the right. The sequences are named according to appearance in the NCBI databank. Only apparently full length sequences were included in the alignment. Clarias gariepinus Sox9a ADJ96868, Clarias gariepinus Sox9b ADJ96869, Cynoglossus semilaevis Sox9a ACY05958, Cyprinus carpio Sox9b AAX56088, Danio rerio Sox9a AF277096, Danio rerio Sox9b AF277096, Danio rerio Sox9b AF277097, Danio rerio Sox8 AAX73357, Dicentrarchus labrax SOX9 CBN81190, Epinephelus akaara Sox9 AAT77677, Epinephelus coioides Sox9 ACT10337, Gasterosteus aculeatus Sox9a AAQ62978, Gasterosteus aculeatus Sox9b AAQ62979, Monopterus albus Sox9a1 AF378150, Monopterus albus Sox9a2 AF378151, Odontesthes bonariensis SOX9 AAP84605, Oncorhynchus mykiss SOX9 BAA24365, Oncorhynchus mykiss SOX9a2 AAG43497, Oreochromis aureus SOX9 ABY66377, Oryzias latipes SOX9b AAX62151, Oryzias latipes SOX9a AAX62152, Paralichthys olivaceus Sox9 ACO40490, Poecilia reticulata Sox9 ABG77973, Salmo salar Sox9 ACN10975, Takifugu rubripes Sox9 AAL32172. The Atlantic cod sequences were obtained through Blast search at The Cod Genome Project web site [57] and translated from the Gadus morhua Sox9 ENSGAUG00000009261 (apparent complete open reading length that include the primer sites used in this communication) and Gadus morhua Sox9v ENSGAUG00000015623.
\end{abstract}

\section{Competing interests}

The authors declare they have no competing interests.

\section{Acknowledgments}

We thank Stig Ove Utskot and Rita Karlsen at IMR Austevoll for excellent technical assistance. The work was carried out as part of project no. 172633 (Production of all-female cod as a means to circumvent problems with early puberty in males: Studies on sex determination and differentiation) and grant 159662/S40, both financially supported by the Norwegian Research Council and the Ministry of Fisheries and Coastal Affairs. We would also like to thank sagafjords for supplying juveniles used for histology.

\section{Author details}

${ }^{1}$ Institute of Marine Research, Nordnes, P.O. Box 1870, N-5817, Bergen, Norway. ${ }^{2}$ Utrecht University, Science Faculty, Department of Biology, Padualaan 8, NL-3584 CH, Utrecht, The Netherlands. ${ }^{3}$ University of Bergen, Department of Molecular Biology, HiB, Thormøllensgt. 55, N-5020, Bergen, Norway. ${ }^{4}$ Embrapa Western Amazon, Rodovia AM-10, Km 29, PO Box 319, Manaus AM-Brazil-69010-970, Brazil.

\section{Authors' contributions}

$\mathrm{TH}$ : planned and carried out the study, sampling, gene expression data treatment. Drafted the MS. FFLA: histological analysis and In Situ 
Hybridization. Helped draft MS. EA: carried out and analyzed the gene expression studies. Helped draft MS. JB and KSS: carried out the cloning and developed quantification of gene expression systems. RM: cloning and phylogenetic analysis. RWS: analyzed the histology and ISH, fund raising. Helped draft MS. ES: carried out and developed quantification the gene expression studies. TW: carried out parts of the histology. GLT planned the study, fund-raising, project leader. Helped draft MS. All authors have read and approved the final version.

\section{Received: 21 December 2011 Accepted: 18 June 2012}

Published: 18 June 2012

\section{References}

1. Trippel EA, Benfey TJ, Neil SRE, Cross N, Blanchard MJ, Powell F: Effects of continuous light and triploidy on growth and sexual maturation in Atlantic cod, Gadus morhua. Cybium 2008, 32:136-138.

2. Haugen T, Andersson E, Norberg B, Taranger GL: The production of hermaphrodites of Atlantic cod (Gadus morhua) by masculinization with orally administered $17-a-$ methyltestosterone, and subsequent production of all-female cod populations. Aquaculture 2011, 311:248-254.

3. Donaldson EM, Hunter GA: Sex control in fish with particular reference to salmonids. Can J Fish Aquat Sci 1982, 39:99-110.

4. Yamamoto T: Artificial induction of functional sex reversal in genotypic females of the medaka (Oryzias latipes). J Exp Zool 1958, 137:227-262.

5. Devlin $\mathrm{RH}$, Nagahama Y: Sex determination and sex differentiation in fish: an overview of genetic, physiological, and environmental influences. Aquaculture 2002, 208:191-364.

6. Yoshizaki G, Takeuchi Y, Kobayashi T, Ihara S, Takeuchi T: Primordial Germ Cells: the Blueprint For a Piscine Life. Fish Physiol Biochem 2002, 26:3-12.

7. Balinsky Bl: An Introduction to Embryology. 4th edition. Philadelphia: Saunders; 1975

8. Nakamura M, Takahashi H: Gonadal sex differentiation in Tilapia mossambica, with special regard to the time of estrogen treatment effective in inducing complete feminization of genetic males. B Fac Fish Hokkaido Uni 1973, 24:1-13.

9. Strussmann CA, Nakamura M: Morphology, endocrinology, and environmental modulation of gonadal sex differentiation in teleost fishes. Fish Physiol Biochem 2002, 26:13-29.

10. Hirai N, Nanba A, Koshio M, Kondo T, Morita M, Tatarazako N: Feminization of Japanese medaka (Oryzias latipes) exposed to $17 \beta$-estradiol: Formation of testis-ova and sex-transformation during early-ontogeny. Aquat Toxicol 2006, 77:78-86.

11. Uchida D, Yamashita M, Kitano T, Iguchi T: Oocyte apoptosis during the transition from ovary-like tissue to testes during sex differentiation of juvenile zebrafish. J Exp Biol 2002, 205:711-718.

12. Blazquez $M$, Navarro-Martin L, Piferrer F: Expression profiles of sex differentiation-related genes during ontogenesis in the European sea bass acclimated to two different temperatures. J Exp Zool part B 2009, 312B:686-700

13. Saillant E, Chatain B, Menu B, Fauvel C, Vidal MO, Fostier A: Sexual differentiation and juvenile intersexuality in the Euopean sea bass (Dicentrarchus labrax). J Zool 2003, 260:53-63.

14. Hendry Cl, Martin-Robichaud DJ, Benfey TJ: Gonadal sex differentiation in Atlantic halibut. J fish biol 2002, 60:1431-1442

15. Guiguen Y, Baroiller JF, Ricordel MJ, Iseki K, McMeel OM, Martin SAM, Fostier $\mathrm{A}$ : Involvement of estrogens in the process of sex differentiation in two fish species: The rainbow trout (Oncorhynchus mykiss) and tilapa (Oreochromis niloticus). Mol Reprod Dev 1999, 54:154-162.

16. Guiguen $Y$, Fostier A, Piferrer F, Chang CF: Ovarian aromatase and estrogens: A pivotal role for gonadal sex differentiation and sex change in fish. Gen Comp Endocr 2010, 165:352-366.

17. Kitano T, Takamune K, Nagahama Y, Abe S: Aromatase inhibitor and 17 alpha-methyltestosterone cause sex-reversal from genetic females to phenotypic males and suppression of p450 aromatase gene expression in Japanese flounder (Paralichthys olivaceus). Mol Reprod Dev 2000, 56:1-5

18. Luckenbach JA, Early LW, Rowe AH, Borski RJ, Daniels HV Godwin J: Aromatase cytochrome P450: Cloning, intron variation, and ontogeny of gene expression in southern flounder (Paralichthys lethostigma). J Exp Zool Part A 2005, 303A:643-656.

19. Ijiri S, Kaneko H, Kobayashi T, Wang DS, Sakai F, Paul-Prasanth B, Nakamura M, Nagahama Y: Sexual dimorphic expression of genes in gonads during early differentiation of a teleost fish, the Nile tilapia Oreochromis niloticus. Biol Reprod 2008, 78:333-341.

20. Sudhakumari CC, Kobayashi T, Kajiura-Kobayashi H, Wang DS, Yoshikuni M, Nagahama Y, Senthilkumaran B: Ontogenic expression patterns of several nuclear receptors and cytochrome p450 aromatases in brain and gonads of the Nile tilapia Oreochromis niloticus suggests their involvement in sex differentiation. Fish Physiol Biochem 2005, 31:129-135.

21. Racine C, Rey R, Forest MG, Louis F, Ferre A, Huhtaniemi I, Josso N, Di Clemente N: Receptors for Anti-Müllerian hormone on Leydig cells are responsible for its effects on steroidogenesis and cell differentiation. PNAS 1998, 95:594-599.

22. Josso N, Racine C, Di Clemente N, Rey R, Xavier F: The role of Anti-Mûllerian hormone in gonadal development. Mol Cell Endocrinol 1998, 145:3-7.

23. Skaar KS, Nóbrega RH, Magaraki A, Olsen LC, Schulz RW, Male R: Proteolytically activated, recombinant Anti-Müllerian hormone inhibits androgen secretion, proliferation, and differentiation of spermatogonia in adult zebrafish testis organ cultures. Endocrinology 2011, 152:3527-3540.

24. Rodriguez-Mari A, Yan YL, BreMiller RA, Wilson C, Canestro C, Postlethwait JH: Characterization and expression pattern of zebrafish anti-Müllerian hormone (amh) relative to sox9a, sox9b, and cyp 19a1a, during gonad development. Gene Expr Patterns 2005, 5:655-667.

25. Schulz RW, Bogerd J, Male R, Ball J, Fenske M, Olsen LC, Tyler CR: Estrogen-induced alterations in amh and dmrt1 expression signal for disruption in male sexual development in the zebrafish. Environ Sci Technol 2007, 41:6305-6310.

26. Yoshinaga N, Shiraishi E, Yamamoto T, Iguchi T, Abe S, Kitano T: Sexually dimorphic expression of a teleost homologue of Müllerian inhibiting substance during gonadal differentiation in Japanese flounder, Paralichthys olivaceus. Biochem Bioph Res Co 2004, 322:508-513.

27. Baron D, Houlgatte R, Fostier A, Guiguen Y: Large-scale temporal gene expression profiling during gonadal differentiation and early gametogenesis in rainbow trout. Biol Reprod 2005, 73:959-966.

28. Baron D, Guiguen Y: Gene expression during gonadal sex differentiation in rainbow trout (oncorhynchus mykiss): from candidate genes to high throughout genomic approach. Fish Physiol Biochem 2003, 28:119-123.

29. Park SY, Jameson $\lrcorner$, Minireview: Transcriptional regulation of gonadal development and differentiation. Endocrinology 2005, 146:1035-1042.

30. Von Hofsten J, Olsson PE: Zebrafish sex determination and differentiation: Involvement of FTZ-F1 genes. Reprod Biol Endocrin 2005, 3:63. http://www. rbej.com/content/3/1/63

31. Bouma GJ, Albrecht KH, Washburn LL, Recknagel AK, Churchill GA, Eicher EM: Gonadal sex reversal in mutant Dax 1 XY mice: a failure to upregulate sox9 in pre-Sertoli cells. Development 2005, 132:3045-3054.

32. Wang ZJ, Jeffs $B$, Ito $M$, Achermann JC, Yu RN, Hales DB, Jameson JL: Aromatase (Cyp19) expression is up-regulated by targeted disruption of Dax1. PNAS 2001, 98:7988-7993.

33. Bardoni B, Zanaria E, Guioli S, Floridia G, Worley KC, Tonini G, Ferrante E, Chiumello G, McCabe ERB, Fraccaro M, Zuffardi O, Camerino G: A dosage sensitive locus at chromosome XP21 is involved in male to female sex reversal. Nat Genet 1994, 7:497-501.

34. Volle DH, Duggavathi R, Magnier BC, Houten SM, Cummins CL, Lobaccaro JMA, Verhoeven G, Schoonjans K, Auwerx J: The small heterodimer partner is a gonadal gatekeeper of sexual maturation in male mice. Gen Dev 2007, 21:303-315.

35. Wang DS, Kobayashi T, Senthilkumaran B, Sakai F, Sudhakumari CC, Suzuki T, Yoshikuni M, Matsuda M, Morohashi Kl, Nagahama Y: Molecular cloning of Dax1 and SHP CDNAs and their expression patterns in the Nile tilapia, Oreochromis niloticus. Biochem Bioph Res Co 2002, 297:632-640.

36. Sandra GE, Norma MM: Sexual determination and differentiation in teleost fish. Rev Fish Biol Fisher 2010, 20:101-121.

37. Wagner T, Wirth J, Meyer J, Zabel B, Held M, Zimmer J, Pasantes J, Bricarelli FD, Keutel J, Hustert E, Wolf U, Tommerup N, Schempp W, Scherer G: Autosomal sex reversal and campomelic dysplasia are casued by mutations in and around the sry-related gene sox9. Cell 1994, 79:1111-1120.

38. Vidal VPI, Chaboissier MC, de Rooij DG, Schedl A: Sox9 indices testis development in XX transgenic mice. Nat Genet 2001, 28:216-217.

39. Chiang EFL, Pai Cl, Wyatt M, Yan YL, Postlethwait J, Chung BC: Two sox9 genes on duplicated zebrafish chromosomes: Expression of similar transcription activators in distinct sites. Dev Bio 2001, 231:149-163. 
40. Kluver $\mathrm{N}$, Kondo M, Herpin A, Mitani H, Schartl M: Divergent expression patterns of Sox9 duplicates in teleosts indicate a lineage specific subfunctionalization. Dev Genes Evol 2005, 215:297-305.

41. Vizziano D, Randuineau G, Baron D, Cauty C, Guiguen Y: Characterization of early molecular sex differentiation in rainbow trout, Oncorhynchus mykiss. Dev Dynam 2007, 236:2198-2206.

42. Chiasson M, Benfey TJ, Martin-Robichaud DJ: Gonadal differentiation in Atlantic cod, Gadus morhua (L.), and haddock, Melanogrammus aeglefinus (L.). Acta Ichthyol Piscat 2008, 38:127-133.

43. Mittelholzer C, Andersson E, Consten D, Hirai T, Nagahama Y, Norberg B: 20 beta-hydroxysteroid dehydrogenase and cyp19a1 are differentially expressed during maturation in Atlantic cod (Gadus morhua). J Mol Endocrinol 2007, 39:319-328.

44. Bogerd J, Blomenrohr M, Andersson E, van der Putten $H$, Tensen CP, Vischer HF, Granneman JCM, Janssen-Dommerholt C, Goos HJT, Schulz R: Discrepancy between molecular structure and ligand selectivity of a testicular follicle-stimulating hormone receptor of the African catfish (Clarias gariepinus). Biol Reprod 2001, 64:1633-1643.

45. Weltzien FA, Norberg B, Helvik JV, Andersen O, Swanson P, Andersson E: Identification and localization of eight distinct cell types in the pituitary of male Atlantic halibut (Hippoglossus hippoglossus L.). Comp Biochem Phys A 2003, 134:315-327.

46. Nakamura M, Kobayashi T, Chang XT, Nagahama Y: Gonadal sex differentiation in teleost fish. J Exp Zool 1998, 281:362-372.

47. Lewis ZR, McClellan MC, Postlethwait JH, Cresko WA, Kaplan RH: Female-specific increase in primordial germ cells marks sex differentiation in three-spine Stickleback (Gasterosteus aculeatus). J Morphol 2008, 269:909-921.

48. Rasmussen $T H$, Jesperesen $\AA$, Korsgaard B: Gonadal morphogenesis and sex differentiation in intraovarian embryos of the viviparous fish Zoarces viviparous (Teleostei, Perciformes, Zoarcidae): A histological and ultrastructural study. J Morphol 2006, 267:1032-1047.

49. Yoon C, Kawakami K, Hopkins N: Zebrafish vasa homologue RNA is localized to the cleavage planes of 2- and 4-cell-stage embryos and is expressed in the primordial germ cells. Development 1997, 124:3157-3165.

50. Yoshizaki G, Takeuchi Y, Sakatani S, Takeuchi T: Germ cell-specific expression of green fluorescent protein in transgenic rainbow trout under control of the rainbow trout vasa-like gene promoter. Int J Dev Biol 2000, 44:323-326.

51. Tanaka M, Kinoshita M, Kobayashi D, Nagahama Y: Establishment of medaka (Oryzias latipes) transgenic lines with the expression of green fluorescent protein fluorescence exclusively in germ cells: a useful model to monitor germ cells in live vertebrate. P Natl Acad Sci USA 2001, 98:2544-2549

52. Vizziano-Cantonnet D, Anglade I, Pellegrini E, Gueguen MM, Fostier A, Guiguen Y, Kah O: Sexual dimophism in the brain aromatase expression and activity, and in the central expression of other steroidogenic enzymes during the period of sex differentiation in monosex rainbow trout populations. Gen Comp Endocr 2010, 170:346-355.

53. Miura T, Ohta T, Miura Cl, Yamauchi K: Complementary deoxyribonucleic acid cloning of spermatogonial stem cell renewal factor. Endocrinology 2003, 144:5504-5510.

54. Miura T, Miura C, Konda Y, Yamauchi K: Spermatogenesis-preventing substance in Japanese eel. Development 2002, 129:2689-2697.

55. Martins RST, Deloffre LAM, Mylonas CC, Power DM Canario AVM: Developmental expression of Dax1 in the European sea bass, Dicentrarchus labrax: lack of evidence for sexual dimorphism during sex differentiation. Reprod Biol Endocrin 2007, 5:13.

56. Star B, Nederbragt AJ, Jentoft S, Grimholt U, Malmstrom M, Gregers TF, Rounge TB, Paulsen J, Solbakken MH, Sharma A, et al: The genome sequence of Atlantic cod reveals a unique immune system. Nature 2011, 477:207-210,

57. http://codgenome.no/index.php?option=com_content\&view=article\&id= $62 \& \mid$ temid $=85$

doi:10.1186/1477-7827-10-47

Cite this article as: Haugen et al: Sex differentiation in Atlantic cod (Gadus morhua L.): morphological and gene expression studies. Reproductive Biology and Endocrinology 2012 10:47.

\section{Submit your next manuscript to BioMed Central and take full advantage of:}

- Convenient online submission

- Thorough peer review

- No space constraints or color figure charges

- Immediate publication on acceptance

- Inclusion in PubMed, CAS, Scopus and Google Scholar

- Research which is freely available for redistribution 